THE MEDICAL PROFESSION BILL. To Benjamin Hawes, Esq, M.P.

A mong the favourite expressions of a departed statesman was that of "proceeding backwards." How far it is aylicable to the progress of the ill-fated Bills, I leave you, Sir, to determine. Their brief course has been marked by so many incidents, that those who have watched it can scarcely forbear a passing comment on their features.

On the momentous evening when the Augean stable of the medical community was to have been cleaned, there were, it seems, not enough helpers to effect the pro. cess, for Alcides could not, in this instance, perform the labour by bimself; in plain terms, the house was counted out. On this point I presume to differ from the talented Editor of The Lancet, when he terms this a " melancholy" fact; to $m y$ mind it is a star of promise, an indication of the indifference of the Legislature to a Bill so replete with objections; it has, therefore, been allowed in silence to expire.

This, Sir, is the third great warning with which you have been visited : it is but a repetition of the disapprobation which the pro. fession and even the druggists have before expressed of your measure.

It would be ungracious to withhold from you my confidence in your well-wishing to the public and the profession; but, sooth to say, your good intentions have been but ill requited by both.

The profession itself is almost universally dissatisfied, although courtesy may have induced the professional delegates to back out from their opposition to your amended paper. The representatives of the public have evinced their sentiments of this custrato of a Bill, in a mode not to be mistaken.

If the profession has not yet learned the evils resulting from a want of union in its members, I am sure our senators have; they are so bewildered by ex-parte petitions and letters, that they may as well give up legislating, until they have before them the combined or amalgamated sentiments of the whole profession.

You will smile at my folly in hoping for such a thing, but the profession will at length be just to itself, and will, by adopting the principle of mutual concession, preserve their honour and their interests. They may he assured that without this they will be sul. lied and invaded.

The corporations, indeed, are now acting on this principle, as the civet cat in the fable, pressed by the hunters, bites off its precious bag of pomade, and thus at once stops the pursuit. And why should not the profession follow this example, and thus at once legislate for itself? Why can it not see that the mere separation of the science and the trade (chiefly by a judicious change in the constitution of the Apothecaries' Com. pany), would enhance at once the prosperity of the profession itself, and destroy the jealousies of the chemist, which, I have ever asserted, are not entertained without some reason?

Were the hall not a trading mart, its licentiates would not be traders. Were it only a trading mart, who would be its licentiates? Of course the chemists, who would, by the surveillance of the apothecaries, be confined within their own proper sphere. The public would thus have a negative registration, even in the streets, by which they might discriminate between the profession and the trade.

I feel assured that the chemist, if called in conference by the profession, would be induced, by salutary concessions, to submit to the legal restriction on his prescribing, and to the reduction of his per-centage, remembering that the mass of dispensing in large towns will be carried on at his counter.

By this plan, too, there would be far more congeniality between the referee and the general practitioner; for one great cause of their shyness is from the complaint of the latter, that there is an understanding between the physician and the chemist, prescriptions being sent to his chemist which he ought to dispense.

On such a principle you would at once lay the corner-stone of your grand "onefaculty scheme."

To the profession, then, I should say, " unite in a combined petition ;" to Mr. Hawes 1 should say, "wait until this petition be presented." I am, Sir, your obedient servant,

March 22, 1841.

$\Delta$.

\section{REFORM OF THE PROFESSION.}

\section{To the Editor of THE LANCET.}

SIR:-I should feel obliged by the insertion of the following letter to Mr. Hawes in your valuable Journal, if you could con. veniently allow me so much space. I am, Sir, your obedient servant,

\section{EuWard Bagnall.}

\section{To Mr. Hawes.}

SIR :-As your Bill for the regulation of Medical Practice is postponed until Wednesday next, I take the liberty of suggesting to you the defects of the present state of the profession, with the view of directing your attention to the provision of a remedy. Physicians, under the present regulations, cannot charge or recover fees for attendance; they are incapacitated by the Apothecaries' $A c t$, and are amenable to its penalties, for dispensing their own medicines. This state of things requires a total change, and tho 
law should provide for the remuneration of the physician. That the high grade of the profession should be subject to, and under the control of, the lowest, is an anomaly that exists in no other country; more especially constituted, as the apothecaries are, of a trading company of druggists, selfelected, conducting the examinations of candidates in secret, and deriving a large income from licences to practise, which is divided among the wardens and examiners. This income is not beneficial to the licentiates; nor is it directed to the maintenance of the rights and privileges which are supposed to be secured to the members of the company, when they obtain a licence to practise; but when an apothecary feels himself aggrieved, or his sphere of practice is narrowed $b y$ the encroachments of unqualified practitioners, he is (himself) bound to risk the result of a prosecution, borrowing the names of the master and wardens of the Apothecaries' Company; by which, if he obtain a verdict, the company is entitled to one-half of the penalty, the informer to the other; if defeated, he is amenable to the defendant in double costs, and the company escapes scatheless. These abuses have now existed so long, and the anxiety of the profession for relief is so general, that no. thing short of a radical reform will satisfy the members. The College of Physicians and the Apothecaries' Company are now willing to reform themselves (if their professions are to be believed); but this reform would only tend to create greater confusion and a worse state of things than exists at present. I would suggest that there should be one examining body only, selected in equal numbers from the College of Physicians, the College of Surgeons, and the Apothecaries' Company, by election annually, by whom all candidates should in future be examined (without distinction as to medical schools); that those examinations should be conducted in public; that it should be rigid and satisfactory; and that such fees should be paid by candidates for a diploma as should compensate the examiners for their trouble, and leave a surplus towards the expenses of the government in the shape of staup duty : that all qualified members of the profession in actual practice at the passing of the Bill should be recognised as duly qualified; but should (by law) be obliged to enrol their names under the society, and be amenable to its penal statutes, and receive a diploma (without examination) on payment of the stamp duty and customary fees.

To these regulations, I conceive, every member of every grade of the profession would readily assent; and $I$ believe that there is no scheme more likely to ensure the successful working of medical reform; and, at the same time that we establish one uniform system of examinations, we render the profession a fruitful source of income to the government, without taxing its members nnreasonably; and, inasmuch as the profession of the law is heavily amerced by government for stamps, fees, \&c., there is no reason why the medical profession should not contribute its quota towards the expenses of the government. I do not propose to abolish any of the existing societies; I would suffer them to exist, and leave it to the option of the profession to obtain diplomas from either or from all as an honorary distinction, but not as a matter of compulsion. It would also be desirable to facilitate the recovery of the fees of the profession for attendance, medicines, \&c.; allowing (in case of dispute as to charges) a reference to the examining body, who should have the power to tax disputed bills and award costs. I am, Sir, your obedient servant,

Edward Bagnall

\section{ABUSES IN ST. GEORGE'S.}

\section{To the Editor of The LAncet.}

Sir :-A letter appeared in The LanceT of last Saturday, signed a "Medical Student," to which I would wish to say a few words in answer, which $I$ am sure will find insertion in the pages of your Journal, professing, as it does, to do all in its power to correct abuses, though not at the expense of truth itself.

Your correspoudent is evidently one of those industrious, wrong-headed young gentlemen, who do nothing but gape about the wards of a hospital, for the mere purpose of finding out faults, where, perhaps, none exist.

It is stated, in the letter alluded to, that Dr. Seymour " manages to give as little information in an hour's time as any man he ever heard." Now, I would refer the "Medical Student," and your readers generally, to The Lancet of the 27th of February last, containing clinical lectures by $\mathrm{Dr}$. Seymour, and let them judge for themselves. As for Dr. Seymour's instruction in the wards, I can only say that he gives his pupils the result of a long experience, in a most amusing and clever manner; and it matters not whether the maladies to which he alludes have been inflicted upon a pauper or a peer, so that they afford the necessary instruction.

With regard to Dr. Hope and his clerks, it is true he possesses a little medical mag. nificence, but there is no doubt of his being a clever man; his works will alone prove that fact. And if he prefer to have a clerk, who has some knowledge of the stethoscope, the pupils have every opportunity to qualify thenselves for that duty in the wards of the hospital hy works on that subject, and by the remarks of Dr. Hope himself. This, surely, is better than allowing incorrect facts, mistaken bruits and râles, to be inserted in the clinical report book; subjecting the 